\title{
Occurrence of Escherichia coli harbouring stx genes in popiah, a Malaysian street food
}

\author{
${ }^{1 *}$ Elexson, N., ${ }^{2}$ Nik Yuhanis, F.N., ${ }^{2}$ Malcolm, T.T.H., ${ }^{2}$ New, C.Y., ${ }^{2}$ Chang, W.S., \\ ${ }^{2}$ Ubong, A., ${ }^{2}$ Kuan, C.H., ${ }^{2}$ Loo, Y.Y., ${ }^{2}$ Thung, T.Y. and ${ }^{2,3}$ Son, R. \\ ${ }^{l}$ Department of Biology Molecule, Faculty of Resource Science and Technlogy, \\ Universiti Malaysia Sarawak, 94300 Kota Samarahan, Sarawak, Malaysia \\ ${ }^{2}$ Department of Food Science, Faculty of Food Science and Technology, \\ Universiti Putra Malaysia, 43400 UPM Serdang, Selangor Darul Ehsan, Malaysia \\ ${ }^{3}$ Food Safety and Food Integrity, Institute of Tropical Agriculture and Food Security, \\ Universiti Putra Malaysia 34300 Serdang, Selangor, Malaysia
}

Article history:

Received : 25 January 2017

Received in revised form :

12 February 2017

Accepted : 12 February 2017

Available Online :

17 February 2017

Keywords:

Escherichia coli,

popiah,

MPN-PCR,

stx genes,

street food

DOI:

http://doi.org/10.26656/

fr.2017.1.008

\begin{abstract}
Irrespective of its health effects, street foods are very popular with the consumers. The main purpose of this research was to study the biosafety of Escherichia coli in popiah, a Malaysian street food sold at a roadside food stall and a restaurant in Sri Serdang, Selangor, Malaysia, using the combination of the most probable number (MPN)-Polymerase Chain Reaction (PCR) assay-plating on Eosin Methylene Blue (EMB) agar methods. Using these biomolecular methods, E. coli was detected in 12/15 (80\%) and 11/15 (73\%) of the collected samples from the roadside food stall and the restaurant respectively. The incidence of stx virulence-associated genes was detected in 1/15 (7\%) among the E. coli isolated from samples taken from the roadside food stall while the $E$. coli isolated from the restaurant was $3 / 15(20 \%)$. The density of $E$. coli ranged from $<3$ to $>1100 \mathrm{MPN} / \mathrm{g}$ and the density of $E$. coli positive with stx genes was $<3$ to $53 \mathrm{MPN} / \mathrm{g}$ in samples from both the roadside food stall and the restaurant. The presence of the stx-positive E. coli in popiah are significant to risk assessments of food and epidemiological studies. Therefore, from the information obtained in this study, it is obvious that the screening for STEC markers in food samples would be useful for food safety survey.
\end{abstract}

\section{Introduction}

It is now a well-accepted fact that street food vending represents an important food security strategy for low-income communities worldwide. However, more stringent measures must be promoted in street food vending to integrate the prevention of biological risk factors in order to promote comprehensive and up-to-date consumer safety as these foods are most commonly sold in the streets, public places, busy market places, school areas, near college campuses, and taxi stands, etc. Thus, the safety of street foods has been a source of concern to consumers due to its popularity, particularly in relation to their microbiological contamination.

Popiah, is a Malaysian street food favoured by many. It is mostly made with a filling of shredded raw vegetables, and various studies has shown that raw vegetables represent an important source of risk for human health because they are carriers of pathogenic micro-organisms (Harris et al., 2003; Park et al., 2012). The Enteroaggregative E. coli (EAEC), Enteropathogenic E. coli (EPEC), Enterotoxigenic
E. coli (ETEC), Enteroinvasive E. coli (EIEC) and non-O157 Shiga toxin-producing $E$. coli are the important causative agents of diarrhea in developed countries (Nataro and Kaper, 1998; Nataro, 2004; Estrada-Garcia et al., 2005, 2009). However, STEC strains, harbouring the stx genes is one of the most important recently emerged groups of food borne pathogens, and can contaminate fresh vegetables via primary contamination (while growing and during harvest) or secondary contamination (during washing, slicing, soaking, packaging and preparation) (Harris et al., 2003).

To reduce the exposure of humans to this agent, the detection of $E$. coli based on its recovery from food samples and confirming the presence of its virulence associated factors (shiga-toxins) (Vernozy-Rozand, 1999) is a central goal. Conventional methods are still regarded as the basic tools for isolation, detection, and identification of foodborne pathogens since not all laboratories in developing countries have sufficient resources to incorporate PCR methods in their analytical procedure. The objective of this study was to determine the incidence and density of E. coli 
and $E$. coli harbouring the stx genes in popiah using biomolecular method.

\section{Materials and methods}

\subsection{Sampling method}

A total of 30 popiah samples were randomly collected directly from a roadside food stall and a restaurant in Sri Serdang, Selangor, Malaysia. The two sampling sites were visited once a week for sample collection. Samples were collected aseptically in pre-sterile poly-bags and, then were transferred to the laboratory for immediate analysis.

\subsection{Most probable number count}

Ten grams of sample was homogenized with $90 \mathrm{ml}$ of $0.85 \%(\mathrm{w} / \mathrm{v})$ sterile physiological saline solution in a stomacher laboratory blender (400, Seward, Worthing, UK) for $1 \mathrm{~min}$. The most probable number (MPN) count of E. coli was determined following the method of Cappuccino and Sherman (1998). Turbid MPN tubes were further streaked on Eosin Methylene Blue (EMB) agar (M317, HiMedia) plates and incubated at $37^{\circ} \mathrm{C}$ for $18-24 \mathrm{~h}$. Distinctive metallic green sheen colonies were picked and screened for the presence of the stx genes Polymerase Chain Reaction (PCR).

\subsection{PCR screening for stx genes}

A well isolated colony was transferred to $2 \mathrm{ml}$ of TSB and incubated overnight in an incubator shaker. A $1 \mathrm{ml}$ portion of the cultures was centrifuged at 15,000 $\mathrm{x} g$ for $1 \mathrm{~min}$. The pellet was re-suspended in $500 \mu \mathrm{l}$ sterile distilled water and vortexed vigorously. The cell suspension was boiled for $10 \mathrm{~min}$, immediately chilled on ice for $10 \mathrm{~min}$ and centrifuged again at $15,000 \times \mathrm{g}$ for $1 \mathrm{~min}$. The supernatant containing crude DNA was transferred into a new $1.5 \mathrm{ml}$ microcentrifuge tube and $5 \mu \mathrm{l}$ was used as DNA template in PCR. All DNA samples were screened for the presence of stx genes by PCR as described by He et al. (2012). The PCR product was analysed by electrophoresis on $2 \%$ agarose gel and stained with $0.3 \mu \mathrm{g} / \mathrm{mL}$ ethidium bromide for visualization of the amplicons under UV light gel documentation system (Alpha Imager ${ }^{\circledR}$, Alpha Innotech).

\section{Results and discussion}

Popiah is a popular street food in Malaysia and, it is also one of the popular dishes served at home. Most vendors prepare popiah at their homes before being sold in the streets, public places, busy market places, school areas, near college campuses, and taxi stands, etc. The changes in consumer food behaviours and food patterns have led to an increase in the demand for pre-prepared ready-to-eat (RTE) foods or snacks, such as popiah, and that few data are currently available on the occurrence of E. coli in such foods in Malaysia. In fact, minimal studies were conducted on the pathogen prevalence in street foods in most countries. E. coli was detected in 12/15 $(80 \%)$ and $11 / 15(73 \%)$ of the popiah collected from the roadside food stall and the restaurant, respectively (data not shown). Studying the incidence of stx virulence-associated genes revealed the presence of the stx genes in $1 / 15(7 \%)$ and $3 / 15(20 \%)$ among the $E$. coli isolates tested from popiah samples from the road side stall and the restaurant, respectively (data not shown) and E. coli harbouring stx genes are presumably known as STEC. The density of $E$. coli ranged from $<3 \mathrm{MPN} / \mathrm{g}$ to $>1100 \mathrm{MPN} / \mathrm{g}$ while the density of $E$. coli positive for the stx genes was $<3 \mathrm{MPN} / \mathrm{g}$ to $53 \mathrm{MPN} / \mathrm{g}$ in samples from both the roadside food stall and small restaurant (data not shown). The presence of $E$. coli and E. coli harbouring stx genes is generally related to the low hygiene and sanitation knowledge and practice of the food handlers. It should be noted that microbial population is not well-distributed in food and the transfer of the pathogen from one food to another could presumably due to the same point of contact such as the utensils used, in which will have an increased percentage of transmission when low hygiene and sanitation is being practiced. Several studies were conducted to evaluate the knowledge, attitude and practice of food hygiene and sanitation among the food handlers in Malaysia and the outcome of the studies revealed that Malaysian food handlers had a moderate to high levels (Saad et al., 2013; Mohd. Firdaus Siau et al., 2015). It is possible to rule out this factor with the reported results but what seems to be the problem here is the lack of consistent practice by the food handlers. Furthermore, the complexity of the food supply chain from the initial process to the final process allows many intervention and possible unwanted contaminations of the pathogen.

On the other hand, the shredded raw vegetables, i.e. bean sprouts, used as a filling of the popiah are normally washed with tap water. The water used could be a source of contamination of $E$. coli, if it is poorly treated. In addition, raw vegetables such as bean sprouts may represent an important source of risk for human health because they can become carriers of pathogenic micro-organisms (Harris et al., 2003; Park et al., 2012). Indeed, their complex surface and porosity, unfortunately facilitate the pathogen attachment which leads to their survival 
(Report of the Scientific Committee on Food, 2002; Said, 2012). The popiah will be a direct exposure route of the pathogen to humans as this ready-to-eat street food is consumed without further treatment that would eliminate or reduce the microbial load. As STEC is often the top foodborne pathogens, their exponential growth in human guts with only minimal cells can cause foodborne illness with a high likelihood. In our study, it is interesting to note that there was an obvious difference in the occurrence of STEC contamination between the roadside food stall and the restaurant. This fact might be explained by the different environment and management of the roadside food stall and the restaurant. Usually, in small settings as conducted in this study, it is unable to trace the food sale chain. Some stall keepers produced food by themselves while others purchased food from individual or part-time popiah makers, hence the food sale chain is rather complex and has no obvious information for trace back.

Diarrheagenic E. coli pathotypes (DEPs) are important foodborne pathogens (Kaper et al., 2004) and are classified per their unique virulence traits: Shiga toxin-producing E. coli (STEC); enteroaggregative $E$. coli (EAEC); diffuse adherent E. coli (DAEC); enteroinvasive E. coli (EIEC); enterotoxigenic E. coli (ETEC); enteropathogenic E. coli (EPEC); and entero-aggregative-hemorrhagic E. coli (EAHEC). Non-STEC strains are mostly commensal bacteria in animals, with a high potential for food-borne transmission to humans (Caprioli et al., 2005), though the majority of non-STEC strains have low virulence. However, a food-borne outbreak involving an EAHEC strain (E. coli O104:H4) originating from sprouts in Germany and France (Buchholz et al., 2011), was reported to have acquired the stx genes (Muniesa et al., 2012; Grad et al., 2013) illustrates on how the mobile stx genes can be transferred to different classes of pathogenic E. coli, making them hypervirulent pathogens and having the potential to emerge as new Shiga toxin-producing $E$. coli strains (Muniesa et al., 2012; Grad et al., 2013). This also justifies the purpose of this study to screen for the presence of stx genes.

Street foods is the "traditional fast food" of developing countries, as opposed to the growing presence of "factory cooking" or "fast food" and the consumption patterns (frequency and regularity of consumption) vary from country to country and are influenced by the national and/or regional food cultures. The results obtained in our research provided important information on the health risks associated with the direct consumption of street foods. The risks associated with the street foods can further be controlled and made well-mitigated if all the stakeholders play their roles efficiently (consumers, vendors and government authorities), and be promoted as an alternative in ensuring food security for low-income group urban populations.

\section{Acknowledgement}

Research fund was sponsored by Fundamental Research Grant Projects (FRGS/1/2014/SG05/ UPM/01/2) from the Ministry of Education, Malaysia

\section{References}

Altekruse, S.F., Cohen, M.L. and Swerdlow, D.L. (1997). Emerging foodborne diseases. Emerging Infectious Diseases, 3, 285-293.

Barro, N., Bello, A.R., Itsiembou, Y., Savadogo, A., Ouattar, C.A.T., Nikiema, P.D.S.C. and Traore, A.S. (2007). Street vended foods improvement: contamination mechanism and application of food safety objective strategy: critical review. Pakistan Journal of Nutrition, 6,1-10.

Buchholz, U., Bernard, H., Werber, D., Bohmer, M.M., Remschmidt, C., Wilking, H., Delere, Y., An der Heiden, M., Adlhoch, C., Dreesman, J., Ehlers, J., Ethelberg, S., Faber, M., Frank, C., Fricke, G., Greiner, M., Hohle, M., Ivarsson, S., Jark, U., Kirchner, M., Koch, J., Krause, G., Luber, P., Rosner, B., Stark, K. and Kuhne, M. (2011). German outbreak of Escherichia coli O104:H4 associated with sprouts. New England Journal of Medicine, 365, 1763-1770.

Cappuccino, J .and Sherman, N. (1998). Microbiology: a laboratory manual. 3rd ed. London (UK): Academic Press.

Caprioli, A., Morabito, S., Brugere, H. and Oswald, E. (2005). Enterohaemorrhagic Escherichia coli: emerging issues on virulence and modes of transmission. Veterinary Research, 36, 289-311.

Cohen, M. and Garrett, J.L. (2010). The food price crisis and urban food (in) security. Environment and Urbanization, 22(2), 467-482.

Dawson, R.J. and Canet, C. (1991). International activities in street foods. Food Control, 2, 135-139.

Ekanem, E.O. The street food trade in Africa: safety and socio-environmental issues. Food Control, 9, 211-215.

Estrada-Garcia, T., Cerna, J.F., Paheco-Gil, L., Velazquez, R.F., Ochoa, T.J., Torres, J. and DuPont, H.L. (2005). Drug-resistant diarrheogenic Escherichia coli, Mexico. Emerging Infectious Diseases, 11, 13061308.

FAO. (2000). FAO Technical Support for Improvement within the Street Food Sector. GAUTENG PROVINCE, Pretoria.

Grad, Y.H., Godfrey, P., Cerquiera, G.C., MarianiKurkdjian, P., Gouali, M., Bingen, E., Shea, T.P., Haas, B.J., Griggs, A., Young, S., Zeng, Q., Lipsitch, M., Waldor, M.K., Weill, F.X., Wortman, J.R. and Hanage, 
W.P. (2013). Comparative genomics of recent Shiga toxinproducing Escherichia coli O104:H4: short-term evolution of an emerging pathogen. Ambio, 4, e00452.

Hanashiro, A., Morita, M., Matte, G.R., Matte, M.H. and Torres, E.A.S. (2005). Microbiological quality of selected foods from a restricted area of Sao Paulo city, Brazil. Food Control, 16, 439-444.

He, X., Quinones, B., McMahon, S. and Mandrell, R. E. (2012). A single-step purification and molecular characterization of functional Shiga toxin 2 variants from pathogenic Escherichia coli. Toxins, 4(7), 487504.

Kaper, J.B., Nataro, J.P. and Mobley, H.L. (2004). Pathogenic Escherichia coli. Nature Reviews Microbiology, 2, 123-140.

Kharel, N. and Tamang, J.P. (2010). Street foods: risk and safety. Journal of Hill Research, 23, 1-9.

Lachat, C., Khanh, le N.B., Huynh, T.T., Verstraeten, R., Nago, E., Roberfroid, D. and Kolsteren, P. (2009). Eating out of home in Vietnamese adolescents: socioeconomic factors and dietary associations. American Journal Clinical Nutrition, 90, 1648.

Mohd. Firdaus Siau, A., Son, R., Mohhiddin, O., Toh P.S. and Chai, L.C. (2015). Food court hygiene assessment and food safety knowledge, attitudes and practices of food handlers in Putrajaya. International Food Research Journal, 22(5), 1843-1854.

Muniesa, M., Hammerl, J.A., Hertwig, S., Appel, B. and Brüssow, H. (2012). Shiga toxin producing Escherichia coli O104:H4: a new challenge for microbiology. Applied and Environmental Microbiology, 78, 40654073.

Nataro, J.P. (2004). Enteroaggregative Escherichia coli. In: Scheld, W.M., Murray, B.E. and Hughes, J.M. (Eds.), Emerging infections 6, p. 101-110. Washington, D.C: ASM Press

Nataro, J.P. and Kaper, J.B. (1998). Diarrheagenic Escherichia coli. Clinical Microbiology Reviews, 11, 142-201.

Ohiokpehai, O. (2003). Nutritional aspects of street foods in Botswana. Pakistan Journal of Nutrition, 2(2), 7681.

Park, S., Szonyi, B., Gautam, R., Nightingale, K., Anciso, J. and Ivanek, R. (2012). Risk factors for microbial contamination in fruits and vegetables at the preharvest level: a systematic review. Journal of Food Protection, 75, 2055-2081.

Ponka, A., Maunula, L., von Bonsdorff, C.H. and Lyytikainen, O. (1999). An outbreak of calicivirus associated with consumption of frozen raspberries. Epidemiology and Infection, 123, 469-474.

Rane, S. (2011). Street vended food in developing world: hazard analyses. Indian Journal of Microbiology, 51(1), 100-106.

Report of the Scientific Committee on Food, 2002. Risk profile on the microbiological contamination of fruits and vegetables eaten raw. Retrieved on the February 3, 2017 from: http://ec.europa.eu/ food/fs/sc/scf/out125 en.pdf.
Saad, M., Toh, P.S. and Mohamed Adil, M.A. (2013). Hygiene Practices of Food Handlers at Malaysian Government Institutions Training Centers. In AcE-Bs 2013 Hanoi (ASEAN Conference on EnvironmentBehaviour Studies), Hanoi Architectural University, Hanoi, Vietnam, 18-21 March 2013. Procedia-Social and Behavioural Sciences, 85, 118-127.

Said, D.E.S. (2012). Detection of parasites in commonly consumed raw vegetables. Alexandria Journal of Medicine, 48, 345-352.

Sudershan, R.V., Subbarao, G.M. and Polasa, K. (2009). Making Hyderabad the street food capital of India. A strategy. Hyderabad: National Institute of Nutrition, Indian Council of Medical Research.

World Health Organization (WHO). (1996). Essential safety requirements for street vended foods, revised edition. Geneva (Switzerland): WHO. 